\title{
Energy and Economic Evaluation of Photovoltaic Power Plant Using PVsyst
}

\author{
Sumita, Ankit Agarwal, Praveen Saraswat \\ Department of Mechanical Engineering, Swami Keshvanand Institute of Technology, Management and \\ Gramothan, Jaipur-302017 (INDIA) \\ Email-sumita281@gmail.com \\ Received 31.07.2020, accepted 06.10.2020
}

\begin{abstract}
India's energy scenario has changed in recent years. The Intended Nationally Determined Contribution (INDC) commitment towards climate change of reducing the emission to $0.604 \mathrm{~kg} / \mathrm{kWh}$ has set the new target of renewable source capacity to reach $175 \mathrm{GW}$ by the year 2022. India's tropical climate condition favours the capability of renewable energy sources, among them direct use of solar radiation and wind can be harnessed effectively to increase the energy capacity. Solar is the most secure, copious and non-polluting source of energy. The photovoltaic system capture the solar radiation has emerged as global player and the government has targeted to install $100 \mathrm{GW}$ (40 GW rooftop capacity) of grid connected PV installation by the year 2022 .

The PV power plant located at Mechanical Engineering Department of SKIT, Jaipur is studied to evaluate the performance under the composite climate condition. The performance indices include the energy and economic parameters such as reference yield, array yield, final yield net present value, cost of energy and money payback period. The analysis involves a simulation tool PVsyst. The energy parameters found for the installed capacity also involve performance ratio, calculated throughout the year. The result shows the final yield for the plant as $4.5 \mathrm{kWh} / \mathrm{kWp} / \mathrm{day}$. The economic evaluation shows the money payback period as 4.2 years.
\end{abstract}

Keywords: Energy Generation, PV, Economic Evaluation, Money Payback period

\section{INTRODUCTION}

Renewable energy sources (RES) are playing in the mainstream of the electricity generating system. With the increase in economic growth, demand for electricity has been increased. The world production of electricity has been recorded as 25721 TWh for the year 2017.The contribution shared by combustible fuel was $66.8 \%$ and by hydropower $16.3 \%$. The other renewable energy share was of nuclear $10.2 \%$, wind $4.4 \%$, solar $1.8 \%$, and other $0.5 \%$ of total gross world electricity production [1]. The installed capacity of renewables increased to $2378 \mathrm{GW}$ by the end of the year 2018, with the addition of 181 GW. Solar PV led the addition by accounting $55 \%$ of added capacity followed by wind $28 \%$ and hydro $11 \%$ [2].
The continuous decreasing cost of the PV system made it a global player in the energy sector.

\subsection{India's Trend in RES}

India's energy sector of electricity is primarily based on coal, which alone is not sufficient to fill the gap of growing demand and supply. On seeing the population of 1.4 billion people, India is a huge market for energy use. For meeting the demand of large number of people and maintaining the economic growth rate there is a strong need to shift from the conventional method of energy generation to the alternate source. In 2019 countries' generation capacity has reached a total of $366 \mathrm{GW}$ with sharing $23 \%$ with the renewables as shown in Figure: 1. India's total capacity of renewables hit 86.75 GW in February 2020 including $34.40 \mathrm{GW}$ of solar and $37.66 \mathrm{GW}$ of wind power. The government has planned to raise the share of renewable energy to 55 percent by the year 2030 [3]. In the direction of achieving the target of reducing $\mathrm{CO}_{2}$ emission to $0.604 \mathrm{~kg} / \mathrm{kWh}$ by the year 2021-22 and to cope with the demand, renewable shares need to be increased. It is projected to reduce the 268 million tonnes of $\mathrm{CO}_{2}$ emission by the end of year 2021-22 with the addition of RES [4].

India stands at $5^{\text {th }}$ position in the world in deployment of solar capacity and $4^{\text {th }}$ in wind capacity installation. In last five years, the installed solar capacity has increased to 33712 MW in 2019 with the addition of $5549 \mathrm{MW}$ in 2019 which was 2630 MW in 2014, it is increased by more than 14 times [3]. India's geographical location supports the development of different forms of renewable energy sources. The country is blessed with range of 2300 to 3200 sunshine hours.

The average radiation ranged between 4 to 7 $\mathrm{kWh} / \mathrm{m}^{2} /$ day, including 300 sunny days in a year [5]-[7]. Among the renewable sources, solar energy potential of $750 \mathrm{GW}$ has been reported by the national institute of solar energy. 


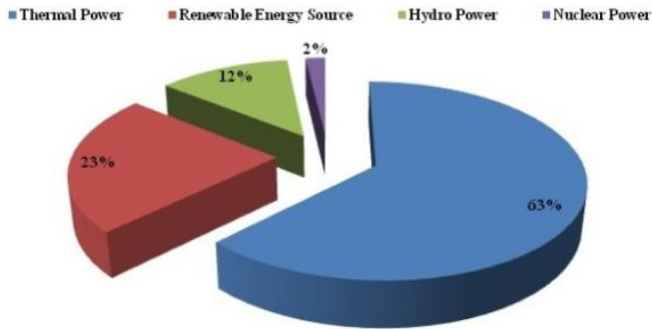

Figure 19: Percentage share of power generation capacity (MW) by different sources as on 31.12.2019 (MNRE, 2019)

\section{SYSTEM DESCRIPTION}

\subsection{Grid-tied PV Power Plant}

The grid-tied photovoltaic power plant became popular nowadays. In this system the generated electricity is utilised by either the connected load and excess of energy is transferred to the local grid or complete generation can be fed to the grid. The PV generation system is connected through a distribution board to the local grid, which records the transfer of energy. The other component includes the inverter for conversion of current according to the requirement of grid. In grid tied system the grid works as unlimited source of storage device as batteries in case of standalone system and supplies electricity when the PV system is unable to generate due to non availability of sunshine or unfavourable weather condition. The facility to sell excess electricity back to the grid encourages the owner to earn money by feed in tariff or by saving in electricity bill. A general configuration of grid-tied PV power plant is as shown in Figure: 2.

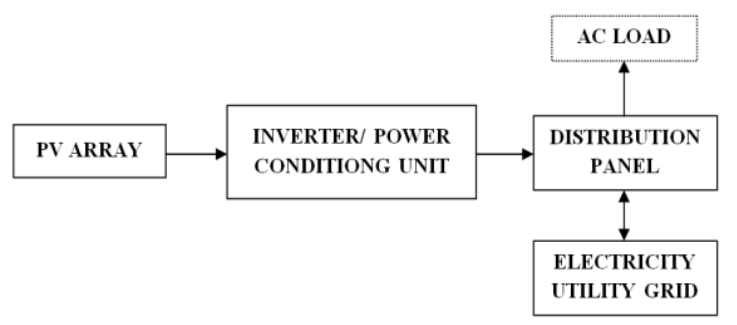

Figure 20: Grid-tied photovoltaic power plant

\subsubsection{Geographical Site Information}

The geographical location of the plant is at latitude $26.90^{\circ} \mathrm{N}$ and longitude $75.80^{\circ}$ E. The yearly average global horizontal irradiation for the plant location is $5.68 \mathrm{kWh} / \mathrm{m}^{2} /$ day and the average ambient temperature and wind velocity remain in a range of $25.1^{\circ} \mathrm{C}$ and 3 to $10 \mathrm{~km} / \mathrm{h}$ respectively [8].

\subsubsection{Plant Layout}

The solar photovoltaic power plant (SPVPP) located at Swami Keshvanand Institute of Technology, Management and Gramothan (SKIT) Jaipur. The plant was built under the scheme of
National Solar Mission (NSM) and commissioned in the year 2015 [9]. With the installation of SPVPP of total capacity of $900 \mathrm{kWp}(400 \mathrm{kWp}$ rooftop and $500 \mathrm{kWp}$ captive), SKIT, Jaipur became the first net zero energy campus of Rajasthan. The SPVPP generates 14 lakh units of electricity in a year and save environmental burden of 1150 Tonnes of carbon dioxide. The green campus of the institute promotes saving of around 34000 trees in a year by consumption of clean energy produced by photovoltaic power plant[10].

The rooftop capacity of $400 \mathrm{kWp}$ installed on the eight blocks of the institute including hostels. The distribution of installed PV capacity in the campus is shown in Table: 1 .

Table 4: Distribution of installed Capacity in SKIT campus

\begin{tabular}{|l|l|l|}
\hline $\begin{array}{l}\text { S. } \\
\text { No. }\end{array}$ & Blocks & $\begin{array}{l}\text { Installed } \\
\text { capacity } \\
\text { (kWp) }\end{array}$ \\
\hline 1 & The Vikram Sarabhai Block & 73.2 \\
\hline 2 & The Dhanvantri Block & 37.2 \\
\hline 3 & Pharmacy Block & 54.9 \\
\hline 4 & The Vishwakarma Block & 62.0 \\
\hline 5 & Sir M. Vishvesvarya Block & 37.2 \\
\hline 6 & Nirwana boys hostel 1 & 55.36 \\
\hline 7 & Nirwana boys hostel 2 & 55.36 \\
\hline 8 & Noran girls hostel & 24.8 \\
\hline
\end{tabular}

The SPVPP installed at the Vishwakarma block (Mechanical Engineering Department) has been selected for study. The plant is installed at the roof with capacity of $62 \mathrm{kWp}$ as shown in Figure: 2

\subsubsection{Specification of Module and Inverter}

The plant is installed with the poly-Si modules of $310 \mathrm{~W}$ manufactured by Renesola Ltd. For the installation of total capacity of $62 \mathrm{kWp}$, total 200 modules are arranged in an array. The array output is fed to the grid connected inverter installed at plant site made by Sungrow power supply Co. Ltd with rated capacity of $50 \mathrm{~kW}$. The inverter also works as data logger system for the power plant.

The specification of module and inverter installed at plant site is given in Table: 2 and 3 respectively.

\begin{tabular}{|l|l|}
\hline \multicolumn{1}{|c|}{ Table 5: Specification of module } \\
\hline Parameters & Values \\
\hline Module type & JC310M-24 \\
\hline Maximum Power & $310 \mathrm{~W}$ \\
\hline Open Circuit Voltage & $45.0 \mathrm{~V}$ \\
\hline Short circuit Current & $8.80 \mathrm{~A}$ \\
\hline MPP Voltage & $37.0 \mathrm{~V}$ \\
\hline MPP Current & $8.38 \mathrm{~A}$ \\
\hline Efficiency & $15.9 \%$ \\
\hline Weight & $27 \mathrm{~kg}$ \\
\hline Dimension $(\mathrm{L} * \mathrm{~W} * \mathrm{H})$ & $1956 * 992 * 40 \mathrm{~mm}$ \\
\hline
\end{tabular}




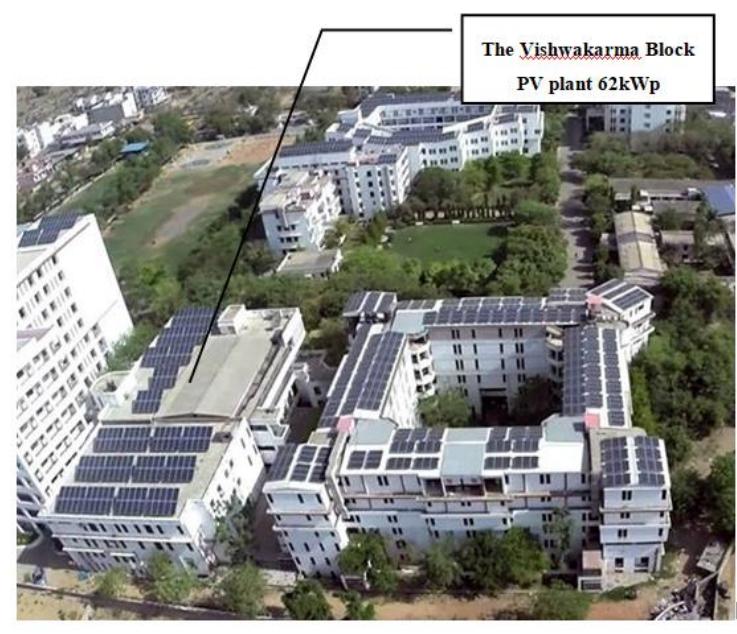

Figure 21: Pictorial view of SPVPP installed at SKIT campus

Table 6: Specification of Inverter

\begin{tabular}{|l|l|}
\hline Parameters & Values \\
\hline Type & SG50KTLM \\
\hline Make & Sungrow \\
\hline Min. MPP Voltage & $300 \mathrm{~V}$ \\
\hline Max. MPP voltage & $950 \mathrm{~V}$ \\
\hline Max. input voltage & $1000 \mathrm{~V}$ \\
\hline Rated output power & $50000 \mathrm{~W}$ \\
\hline Rated output voltage & 3 phase, $400 \mathrm{~V}$ \\
\hline Max. output current & $80 \mathrm{~A}$ \\
\hline Efficiency & $98 \%$ \\
\hline
\end{tabular}

\section{PV POWER PLANT PERFORMANCE INDICES}

Performance indices can be different for the photovoltaic system according to the configuration in which it is involved. The performance of PV power plant is readily compared by the actual energy generation with reference to the standard and maximum power conditions. Such performance indicators are reference yield, system yield, array yield, various losses occurred at different junction of power transmission process and performance ratio etc [11].

Reference Yield: It is defined as the energy output from the PV array as it is operating at its nominal efficiency. It is calculated as the total inplane radiation to the solar radiation at standard condition i.e. $1000 \mathrm{~W} / \mathrm{m}^{2}$. Numerically it represents the sunshine hours for a day if calculated in terms of $\mathrm{kWh} / \mathrm{m}^{2} /$ day [12], and given as:

$$
Y r=\frac{\text { total in plane radiation }(\mathrm{Ht})}{\text { reference radiation }(\mathrm{Go})}
$$

Array Yield: It defines the DC energy output from the PV array at nominal power rating, and given as:

$$
Y a=\frac{\text { DC energy output (Earray) }}{\text { nominal power rating }(\mathrm{Po})}
$$

The nominal power rating defines the output generation at standard test condition $\left(1000 \mathrm{~W} / \mathrm{m}^{2}\right.$, AM1.5 and $25^{\circ} \mathrm{C}$ ).

Final Yield: it is defined as the ratio of final output of PV plant i.e. AC at the inverter output that is fed to the grid to the nominal power rating.

$$
Y f=\frac{\text { AC energy output (Egrid) }}{\text { nominal power rating }(\mathrm{Po})}
$$

Performance Ratio: It is the ratio of final yield to the reference yield.

$$
P R=\frac{Y f}{Y r}
$$

Losses: The actual output generation from the photovoltaic module vary from the standard condition due to various losses occurred at different stages of power generation system.

Array Capture Loss: It is defined as the difference of reference yield and array yield. The array does not produce the reference yield due to the variation in temperature, dust accumulation, shading effect and mismatch in power tracking [7], [13]-[15], and computed as:

$$
L c=Y r-Y a
$$

System Loss: It is the difference of final yield to the array yield and occurred in system due to the properties of electrical components used in grid integration [7], [13]-[15].

$$
L s=Y f-Y a
$$

The financial analysis involves the capital cost involved in installing the complete photovoltaic power plant including labour cost. The economic evaluation calculates the net present value, money payback period and levelized cost of electricity.

Net Present Value: As long the life of a solar system is, it will generate more energy and as will be the expenses and profits so accounting all expenditure and profit to present value is known as net present value, and it is calculated as:

$$
\text { Netpresentvalue }=\sum_{\mathrm{t}=1}^{\mathrm{n}} \frac{\mathrm{Rt}}{(1+i)^{t}}
$$

Where $\mathrm{R}_{\mathrm{t}}=$ Net flow of income for the year $(\mathrm{t})$ $\mathrm{i}=$ Discount rate that could be earned in alternative investments $\mathrm{n}=$ lifetime of the system

Money payback period (MBPP): It is defined as the duration in which the investment made in installing photovoltaic power plant will be recovered.

$$
M P B P=\frac{N P V}{\text { annualsaving }}
$$

Annual saving is calculated from the annual generation multiplied by electricity tariff. Here the tariff considered for evaluation is ₹8 per kWh [16].

Levelized Energy Cost: It is defined as the cost of energy generated by the PV power plant over the net present cost of plant. 


$$
\mathrm{LEC}=\frac{\sum_{\mathrm{t}=1}^{\mathrm{n}} \frac{(\mathrm{It}+\mathrm{Mt})}{(1+i)^{t}}}{\sum_{\mathrm{t}=1}^{\mathrm{n}} \frac{(\mathrm{Et})}{(1+i)^{t}}}
$$

$I_{t}=$ represents investment and expenses for the year (t)

$M_{t}=$ represents operation and maintenance cost for the year $(\mathrm{t})$

$\mathrm{E}_{\mathrm{t}}=$ represents electricity produced

Return on investment (ROI): It is the ratio of net benefit obtained from the generation of electricity from the photovoltaic power plant to the initial investment made. A negative ROI indicates that the system is not profitable.

$$
R O I=\frac{\text { Net benefit over lifetime }}{\text { Total investment }}
$$

I. PVSYST SimULATION:

PVsyst is a performance evaluation tool for photovoltaic system developed by the University of Geneva. It allows to estimate the performance of PV system accurately based on the input parameter. PVsyst is designed for different configuration of photovoltaic system such as grid connected, standalone and pumping.

In present study the project is selected as grid connected. The field data collected from the plant site for the simulation analysis. The climate information of the site location is selected from the map. The parameters related to the geometry of plane of array entered to the system as tilt and azimuth angle as $26^{\circ}$ and $0^{\circ}$ with fixed tilted plane condition. In the system information, the module and inverter has been selected from the inbuilt database as Renesola and Sungrow made respectively. The program suggests the configuration of array according to the plant size, module and inverter capacity, system layout and default losses applicable for the PV power plant.

\section{RESULT \& DISCUSSION}

\subsection{Energy output}

The energy generation from the photovoltaic power plant is estimated at array and inverter output. Monthly variation of global inclined irradiation (GInI) and the array output (Earray) is presented in Figure: 4. Total yearly GInI at the plant location is $2.14 \mathrm{MWh} / \mathrm{m}^{2}$. The energy generated by PV array at module efficiency of $15.9 \%$ is obtained as $102 \mathrm{MWh}$. The monthly average of energy output and global inclined irradiation is 8.69 MWh and 6.9 MWh respectively.

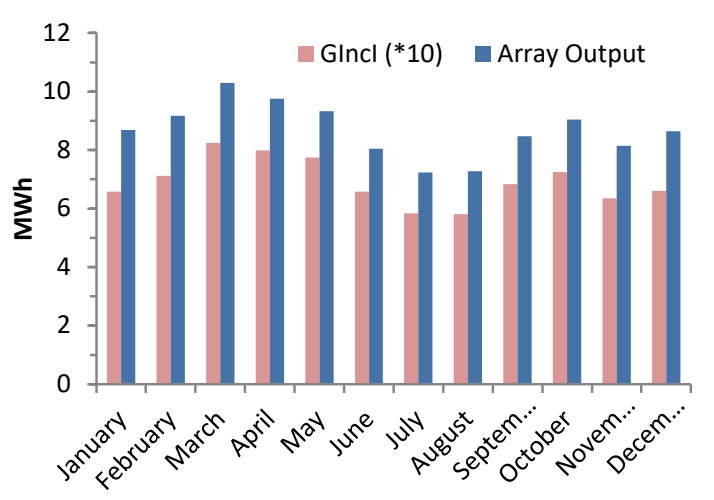

Figure 22: Global inclined radiation and Array output of SPVPP

The maximum and minimum array output is obtained as 10.3 MWh and 7.23 MWh for the month of July and August respectively. The maximum and minimum global inclined irradiation for the plant location is obtained for the same month July and August as $0.15 \mathrm{MWh} / \mathrm{m}^{2}$.

\subsection{Normalised Array Production}

The normalised array production represents the energy generation from the installed power plant as per $\mathrm{kWp}$ capacity that is used to compare the similar power plants. The reference, array and final yield is presented in Figure: 5. Array yield is represented as sum of final yield and system loss (Ls) and reference yield is addition of array yield and capture loss (Lc).

The maximum and minimum reference yield is obtained as 6.86 and $4.83 \mathrm{kWh} / \mathrm{m}^{2} /$ day for April and August month respectively. The maximum and minimum array yield is obtained as $\mathbf{5 . 3 5}$ and 3.76 $\mathrm{kWh} / \mathrm{kWp} /$ day for the month of March and July respectively.

The maximum and minimum final yield 5.28 and $3.71 \mathrm{kWh} / \mathrm{kWp} /$ day for the month of March and July respectively.

The yearly average of reference, array and final yield are obtained as $5.86 \mathrm{kWh} / \mathrm{m}^{2} / \mathrm{day}, 4.6$ and 4.5 $\mathrm{kWh} / \mathrm{kWp} /$ day respectively.

The total array capture loss occurred in a year is $1.25 \mathrm{kWh} / \mathrm{m}^{2} / \mathrm{day}$ due to variation in operating condition. The system losses calculated for a year is found as $0.062 \mathrm{kWh} / \mathrm{kWp} /$ day shown in Figure.5. 


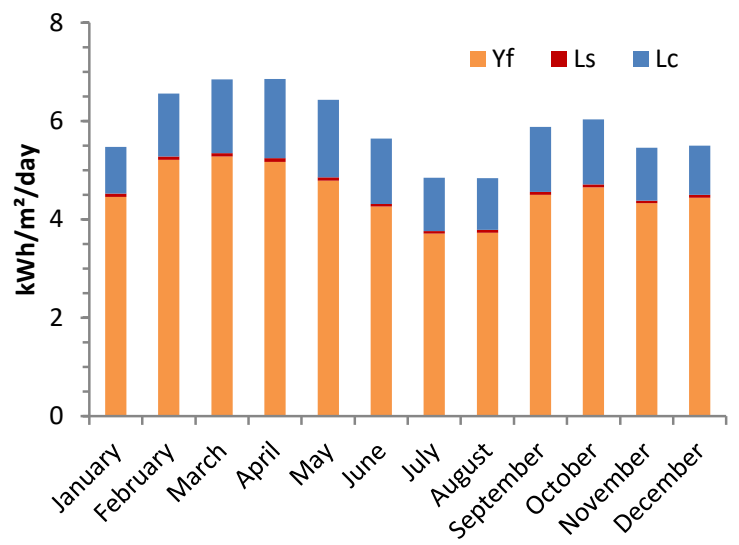

Figure 23: Final yield, System and Array capture loss

\subsection{Losses and Performance Ratio}

The temperature affects the performance of photovoltaic power plant significantly and power loss occurred due to temperature is presented in Figure: 6. Maximum power loss has been observed in month of April and May as 1.28 MWh. The minimum power loss has been seen in month of January 0.46 MWh.

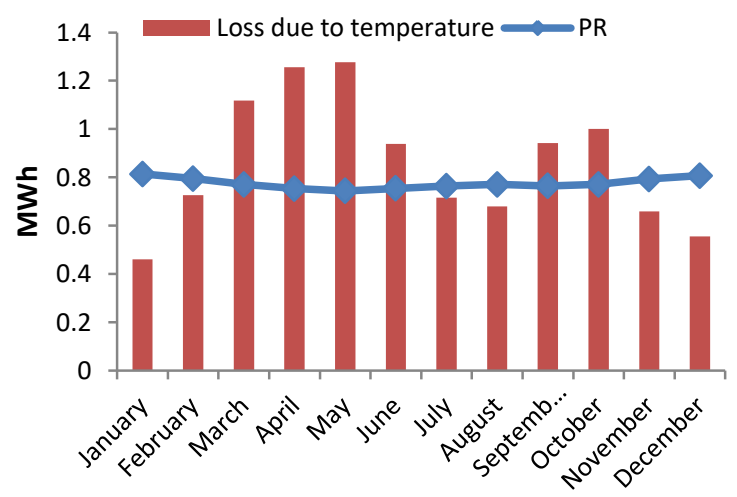

Figure 24: Power loss due to temperature and PR

The performance ratio varies in range of 0.74 to 0.81 and yearly average is obtained as 0.77 shown in Figure: 5

\subsection{Economic Evaluation}

The simulation result for the economic evaluation of studied grid-tied SPVPP considered the installation cost of power plant as $₹ 55 / \mathrm{kWp}$ [17]. All economic parameters are considered for the lifetime of PV of 25 years. The maintenance and operation cost for the plant is considered as $1 \%$ of initial investment and evaluated with the discount rate of $8 \%$. The electricity tariff considered as ₹ 8 for per $\mathrm{kWh}$ of energy consumption form the local grid. The economic evaluation shows the net present value of the plant as ₹5670035. The net income flow from the electricity generation is shown in Figure: 7.

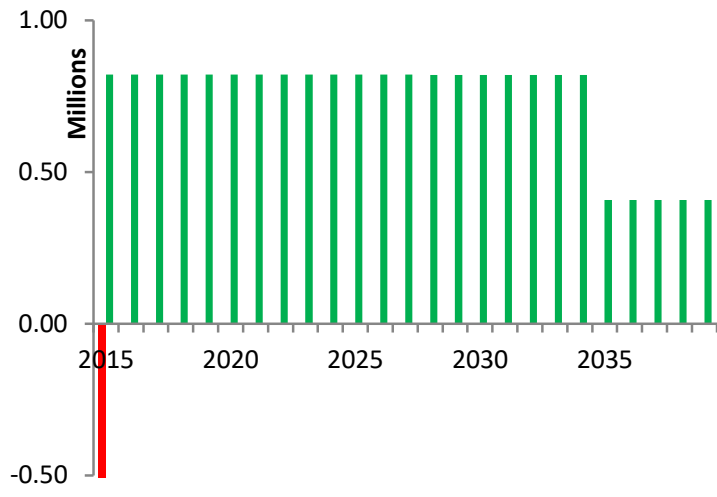

Figure 25: Net income flow diagram

The money payback period shows the duration in which investment made in PV power plant will be recovered and obtained as 4.2 years.

The levelized cost of energy calculated by the simulation shows the price of generated electricity as $₹ 2.90 / \mathrm{kWh}$. The return on investment is calculated as $440 \%$ from the electricity generation by PV power plant.

\section{CONClusion}

The SPVPP located at Mechanical engineering department, SKIT, Jaipur is analysed with simulation software PVsyst. The results are concluded as follows:

- The annual electricity injected to the local grid is $102 \mathrm{MWh} /$ year with specific production of $1659 \mathrm{kWh} / \mathrm{kWp} /$ year.

- The average value of the performance ratio (PR) is obtained as $77 \%$.

- Power loss due to temperature, climate condition, and due to system properties has obtained as $861 \mathrm{kWh} /$ month 1.25 $\mathrm{kWh} / \mathrm{m}^{2} /$ day and $0.062 \mathrm{kWh} / \mathrm{kWp} /$ day.

- The money payback period calculated for the investment made is 4.2 years.

The simulation results concluded that installed $\mathrm{PV}$ power plant system is generating high energy output per installed capacity and sustain the clean energy environment. Further, the user friendly simulation program PVsyst can be used to analyse different photovoltaic configuration and technologies to further improve the performance.

\section{REFERENCES}

[1] IEA, "ELECTRICITY INFORMATION: OVERVIEW," 2019.

[2] REN21.2019., "Renewables 2019 Global Status Report," 2019.

[3] MNRE, “Annual Report 2019-20,” 2019.

[4] Central Electricity Authority, "national electricity planning," 2018.

[5] A. Sharma, "A comprehensive study of solar power in India and World," Renew. Sustain. Energy Rev., vol. 15, 
no. 4, pp. 1767-1776, 2011

[6] F. Ansari, R. Kumar, S. Luthra, S. L. Shimmi, and S. Chatterji, "Analysis of barriers to implement solar power installations in India using interpretive structural modeling technique," Renew. Sustain. Energy Rev., vol. 27, pp. 163-174, 2013.

[7] V. Sharma and S. S. Chandel, "Performance analysis of a $190 \mathrm{kWp}$ grid interactive solar photovoltaic power plant in India," Energy, vol. 55, pp. 476-485, 2013.

[8] synergy enviro Engineers, "Average Global Horizontal Irradiance," 2020. [Online]. Available: synergyenviron.com

[9] A. K. Nayak and D. Singh, "Performance Evaluation of 400 kW Grid Connected Rooftop Solar Photovoltaic Power Plant Installed at SKIT , Jaipur," Ski. Res. J., vol. 9, no. 1, 2019.

[10] SKIT, "Infrastructure." [Online]. Available: Https://www.skit.ac.in/infrastructure.html.

[11] S. K. Yadav and U. Bajpai, "Performance evaluation of a rooftop solar photovoltaic power plant in Northern India," Energy Sustain. Dev., vol. 43, pp. 130-138, 2018.

[12] N. M. Kumar, M. R. Kumar, P. R. Rejoice, and M.
Mathew, "Performance analysis of $100 \mathrm{kWp}$ grid connected Si-poly photovoltaic system using PVsyst simulation tool," Energy Procedia, vol. 117, pp. 180189, 2017.

[13] B. S. Kumar and K. Sudhakar, "Performance evaluation of $10 \mathrm{MW}$ grid connected solar photovoltaic power plant in India," Energy Reports, vol. 1, pp. 184-192, 2015.

[14] IEC, "Photovoltaic System Performance MonitoringGuidelines for Measurement Data Exchange and Analysis," 1998.

[15] C. M. Ayompe LM, Duffy A, Mc Cormack SJ, "Measured performance of a $1.72 \mathrm{~kW}$ rooftop grid connected photovoltaic system in Ireland," Energy Convers. Manag., pp. 1601-1606., 2011.

[16] J. Discom, "Tariff Order," 2020. [Online]. Available: https://energy.rajasthan.gov.in/content/dam/raj/energy/ja ipurdiscom/PDF2020/February2020/JPR1026.pdf.

[17] MNRE, "STANDARD, SPECIFICATION \& BENCHMARK COST," 2019. [Online]. Available: https://mnre.gov.in/img/documents/uploads/2a4e2c9c7c 6a47b098255d07fd752264.pdf. 